ANUVA Volume 2 (1): 107-116, 2018

Copyright C2018, ISSN: 2598-3040 online

Available Online at: http://ejournal.undip.ac.id/index.php/anuva

\title{
Evaluasi Website ANRI (Arsip Nasional Republik Indonesia) Menggunakan Ten C's
}

\author{
Ika Krismayani ${ }^{1 *}$ \\ ${ }^{I}$ Program Studi Ilmu Perpustakaan, Fakultas Ilmu Budaya, Universitas Diponegoro \\ *)Korespondensi: ika.krismayani@live.undip.ac.id
}

\begin{abstract}
Construction of a website does not only stop after the website is built. However, more than that, the construction of a website is done continuously as long as the website is still available, including one of which is the website evaluation process. One method that can be used in website evaluation is Ten C's. The results of Ten C's use of ANRI's website show that in addition to having various advantages such as completeness of information, clarity of vision and mission, and novelty of information, the website also has some weaknesses. Existing weaknesses are related to too much content being displayed, some articles are not equipped with authors, and connectivity is slow at certain hours.
\end{abstract}

\section{Keyword: ANRI; Ten C's}

\begin{abstract}
Abstrak
Pembangunan suatu website tidak semata-mata berhenti setelah website tersebut dibangun. Namun, lebih dari itu, pembangunan suatu website dilakukan secara terus-menerus selama website tersebut masih tersedia, termasuk salah satunya adalah proses evaluasi website. Salah satu metode yang dapat digunakan dalam evaluasi website adalah Ten C's. Hasil penggunaan Ten C's terhadap website milik ANRI menunjukkan bahwa selain memiliki berbagai kelebihan seperti kelengkapan informasi, kejelasan visi dan misi, dan kebaruan informasi, website tersebut juga memiliki beberapa kelemahan. Kelemahan yang ada terkait dengan terlalu banyaknya konten yang ditampilkan, beberapa artikel tidak dilengkapi dengan penulis, dan konektivitas yang lambat pada jam-jam tertentu.
\end{abstract}

\section{Kata Kunci: ANRI; Ten C's.}

\section{Pendahuluan}

Arsip Nasional Republik Indonesia (ANRI) merupakan lembaga arsip yang menyimpan berbagai macam arsip pemerintahan di Indonesia. Munculnya istilah E-goverment telah mendorong lembaga ANRI untuk menerapkan istilah ini dalam kelembagaannya. Salah satu bentuknya adalah dengan membangun website ANRI.

Dalam pengelolaan website tidak hanya berhenti pada proses pembangunan sampai website tersebut bisa diakses saja. Diperlukan juga proses evaluasi dalam rangka menjaga kualitas website yang telah dibangun. Salah satu teori yang dapat digunakan dalam evaluasi website adalah menggunakan Ten C's yang menjadi salah satu metode dalam penelitian di Montgomery College, Montgomery, Maryland (Richmond, 2011). Dalam tulisan ini akan dibahas mengenai evaluasi website ANRI menggunakan Ten C's. Metode ini dipilih karena beberapa indikator di dalamnya dirasa sesuai dengan lembaga kearsipan, seperti dasar hukum, hak cipta, kredibilitas, dan lain-lain. 


\section{Tinjauan Pustaka}

Penulis telah melakukan penelusuran untuk mendapatkan beberapa hasil penelitian sejenis yang pernah dilakukan oleh para peneliti sebelumnya. Dari hasil penelusuran tersebut diperoleh beberapa hasil penelitian sejenis namun tidak serupa dengan yang akan penulis lakukan. Penelitian pertama adalah penelitian yang dilakukan oleh Artana dan Suhartono (2009:2). Penelitian ini dilakukan dalam rangka evaluasi terhadap kondisi website ITS berkaitan dengan penilaian Webometrics, khususnya pemanfaatan web personal dosen. Hasil evaluasi diri berdasarkan kenyataan yang ada diharapkan dapat digunakan sebagai pijakan yang tepat untuk penentuan langkah yang optimal dalam meraih peringkat yang lebih baik pada penilaian Webometrics. Hasil evaluasi pada bulan April 2009 menunjukkan bahwa 25\% dosen yang telah mengisi web personal dosen, $12 \%$ yang menuliskan judul-judul artikelnya, $4 \%$ dosen yang memberikan file artikel yang dapat didownload, dan hanya $6 \%$ dosen yang memberikan materimateri kuliah yang dapat didownload, serta hanya 5\% dosen yang memberikan link pada webnya. Sedangkan evaluasi pada bulan Agustus 2009 menunjukkan bahwa 33\% dosen yang telah mengisi web personal dosen, 15,24\% yang menuliskan judul-judul artikelnya, 5,1\% dosen yang memberikan file artikel yang dapat didownload, dan hanya 6,83\% dosen yang memberikan materi-materi kuliah yang dapat didownload, serta hanya 4,39\% dosen yang memberikan link pada webnya. Hasil ini secara umum menunjukkan bahwa ada sedikit peningkatan jumlah dosen yang memanfaatkan web personal dosen antara bulan April sampai Agustus 2009. Peningkatan ini ternyata tidak sejalan dengan penurunan peringkat ITS pada penilaian Webometrics bulan Juli 2009. Hal ini diduga beberapa perguruan tinggi lain di Indonesia melakukan perbaikan yang lebih signifikan berkaitan dengan penilaian Webometrics.

Penelitian kedua adalah penelitian yang dilakukan oleh Rusidi, Syah, dan Akbar (Rusidi, Syah, dan Akbar, 2011). Penelitian ini mengkaji website pemerintah daerah kabupaten Ogan Komering Ulu (OKU) dan Ogan Komering Ulu Timur (OKU Timur). Hasil dari penelitian ini akan menghasilkan sebuah penilaian terhadap situs dan memberikan masukkan dalam proses pengembangan situs website kedepan. Selain menggunakan usability testing, penelitian ini juga melakukan penilaian situs web menggunakan standar yang sudah dikeluarkan Kementrian Komunikasi Republik Indonesia tahun 2003 dalam Buku Panduan Penyelenggaraan Situs Web Pemerintah Daerah. Hasil penelitian menunjukkan bahwa persentase pengguna dalam mendapatkan informasi didalam situs website kabupaten OKU sebesar $81,26 \%$, persentase pengguna yang tidak mendapatkan informasi didalam situs website kabupaten OKU sebesar 18,74\%. Persentase kesesuaian Situs web pemerintah kabupaten OKU dengan Panduan Penyelenggaraan Situs Web Pemerintah Daerah yang dikeluarkan oleh Kementrian Komunikasi RI tahun 2003 sebesar 27,91\%, persentase bagian yang ada tetapi belum sesuai dengan Panduan Penyelenggaraan Situs Web Pemerintah Daerah yang dikeluarkan oleh Kementrian Komunikasi RI tahun 2003 sebesar $48,84 \%$, dan persentase bagian yang tidak ada dalam situs website kabupaten OKU tetapi diisyaratkan dalam Panduan Penyelenggaraan Situs Web Pemerintah Daerah yang dikeluarkan oleh Kementrian Komunikasi RI tahun 2003 sebesar 23,26\%. Sedangkan Untuk situs website kabupaten OKU Timur saat 
ini tidak bisa dinilai, hal ini disebabkan karena situs website OKU Timur tidak aktif (up) dan hanya muncul headernya saja.

Penelitian ketiga dilakukan oleh Hendiyadi, Syah, dan Akbar (Hendriyadi, Syah, dan Akbar, 2011). Penelitian ini dilakukan untuk mengevaluasi website e-government pemerintah daerah berdasar layanan antar lembaga pemerintah, pemerintah kepada dunia usaha dan pemerintah kepada warga negara serta mengukur kinerja website berdasarkan kriteria usability. Penelitian ini dilakukan dengan menggunakan quisioner sebagai intrumen penelitian yang diberikan dosen, staf dan mahasiswa yang mampu menjalankan dan mengakses internet. Quisioner penelitian terdiri dari pertanyaan dasar, pertanyaan standar layanan e-governement dan pertanyaan usability. Berdasarkan pengolahan data dari 3 (tiga) variabel yang digunakan pada kuisioner di dapat bahwa 100\% responden dapat menemukan website e-government pemerintah daerah. Dari layanan e-government didapat bahwa layanan antar lembaga pemerintah sudah terlaksana sebesar $22,6 \%$, layanan pemerintah kepada warga negara sudah terlaksana sebesar 58,7\% dan layanan pemerintah kepada dunia usaha sebesar $50 \%$.

Dari beberapa hasil penelitian di atas dapat disimpulkan bahwa penelitian yang akan penulis lakukan belum pernah dilakukan oleh para peneliti sebelumnya. Hal ini dapat dilihat dari obyek yang dikaji. Meskipun sama-sama meneliti website, namun ketiga penelitian tersebut tidak mengkaji website milik Arsip Nasional Indonesia. Di samping itu, dilihat dari metode yang digunakan hampir semua penelitian di atas merupakan penelitian kuantitatif. Sedangkan penelitian yang akan penulis lakukan merupakan penelitian kualitatif.

\section{Landasan Teori}

\section{Website ANRI}

Arsip atau yang dalam bahasa Inggris disebut dengan archives merupakan suatu rekaman atau dokumen sebuah institusi yang memiliki nilai dalam jangka waktu tertentu, dapat juga berupa koleksi manuskrip yang berisi catatan pribadi seseorang (Feather, 2003:22). Dalam literatur lain, arsip diartikan sebagai sekumpulan rekod atau dokumen sejarah dan disimpan secara permanen karena memiliki nilai yang abadi (Mortimer, 2007:14). Sebuah dokumen dan rekod yang berhubungan dengan sejarah suatu organisasi dapat juga dikatakan sebagai arsip (Stevenson dan Collin, 2006:10). Arsip juga diartikan sebagai rekod publik atau material terseleksi yang disimpan dalam repository arsip (Prytherch, 2005:29). Dari beberapa pengertian di atas, maka dapat disimpulkan bahwa arsip merupakan Suatu informasi terekam yang berhubungan dengan masa lalu seseorang atau lembaga.

Perkembangan teknologi menuntut para pengelola arsip untuk dapat menerapkan teknologi dalam pengelolaannya, termasuk dalam hal penyebaran informasi arsip. Salah satu bentuk penerapan tersebut adalah penggunaan internet dalam pengelolaan arsip.

Internet sebagai sarana penyebar informasi memiliki bentuk yang sangat beragam. Beberapa lembaga yang menggunakan internet dalam penyebaran informasi mewujudkannya dalam bentuk 
pembuatan website lembaga. Hal ini juga berlaku pada lembaga kearsipan. Beberapa lembaga kearsipan, seperti ANRI telah membangun website yang dapat dikunjungi di http://www.anri.go.id/. Website tersebut berisi berita, publikasi, serta beberapa koleksi arsip di lembaga ANRI.

Untuk memudahkan pengunjung, website ANRI dilengkapi dengan beberapa menu seperti home, lembaga, berita, renstra, lakip, peraturan, pameran, link terkait, layanan, dan data arsiparis. Selain itu, untuk menarik perhatian pengunjung, pada bagian atas website juga dilengkapi dengan diorama sejarah bangsa Indonesia. Dengan berbagai menu dan kelengkapan tersebut, diharapkan masyarakat dapat lebih mudah dalam mengakses informasi mengenai ANRI.

\section{Ten C's}

Ten C's merupakan salah satu metode evaluasi website yang sering digunakan. Metode ini merupakan salah satu metode utama di lingkungan Montgomery College, Montgomery, Maryland (Richmond, 2011). Metode ini berisi sepuluh kriteria yang berkaitan dengan website. Sepuluh kriteria tersebut masing-masing berisi pertanyaan yang menjadi pertanyaan-pertanyaan dalam penelitian, sebagaimana yang tercantum di bawah ini.

\section{Content}

- Apakah fokus konten yang dihasilkan?

- Apakah setiap konten mempunyai judul dan penulisnya dapat diidentifikasi dengan baik?

- Apakah kontennya serius atau hanya guyonan?

- Tanggal berapa konten atau dokumen itu dipublish?

- Apakah konten yang ada merupakan edisi terbaru dan edisi yang sedang eksis?

- Apakah ada konten yang terbaru?

\section{Credibility}

- Apakah pengelola atau penulis mudah diidentifikasi dan nyata adanya?

- Apakah kontennya kredible? Mempunyai otoritaskah? Seharusnya bagaimana?

- Bagaimana domain extensionnya? apakah mencerminkan publisher dari website itu?

\section{Bagaimana website Critical Thinking}

- dapat menerapkan kemampuan dan pemikiran yang matang dalam membangunnya? Meliputi kemampuan, pengalaman.

- Dapatkah diidentifikasi pembuat, publisher, edisi?

- Kriteria apa saja yang bisa dijadikan evaluasi web itu sendiri? 


\section{Copyright}

- Ketika ada tulisan atau content diupdate, bagaimana copyrightnya? Apakah dapat dipertanggungjawabkan?

\section{Citation}

- Apakah isi website merupakan kutipan dari media lain?

- Bagaimana dasar hukum dari tulisan yang dimuat?

\section{Continuity}

- Apakah websitenya akan terus dirawat dan diupdate?

- Apakah mudah mendapatkan informasi ketika ada perubahan domain atau penggantian domain extention?

- Ketika ada konten yang bersambung, apakah ada sambunganya di edisi selanjutnya?

\section{Censorship}

- Apakah forum dimoderasi atau tidak?

- Apakah semua keyword diizinkan untuk di craw oleh seach enggine

- Apakah ada pembatasan untuk intitusi dikaitkan dengan visi dan misi?

- Apakah ada privasi terhadap data pengunjung yang masuk?

\section{Connectivity}

- Jika banyak pengunjung yang mekakses, bagaimana responnya? Apakah semua fitur tetap berfungsi?

- Bagaimana koneksi untuk semua user? Apakah bisa diakses menggunakan berbagai model koneksi internet?

- Apakah semua pengujung harus menggunakan browser yang mendukung grapik dan animasi? bagaimana kalau dalam mode text? Apakah ada softaware khusus untuk bisa melihat kontent?

\section{Comparability}

- Apakah website mudah disimpan kedalam CDROM atau media penyimpanan yang lain?

- Apakah website mempunyai kekomparasian dan kelengkapan informasi?

- Apakah harus ada pencocokan data statistik?

- Apakah bisa dicari mana konten terlama dan terbaru?

\section{Context}


- Jika merupakan website ilmiah, apakah pengunjung mudah menemukan semuanya dalam tulisan website anda?

- Apakah mudah mendapatkan jurnal ilmiah ketika website itu merupakan website riset?

\section{Metode Penelitian}

Penelitian ini merupakan penelitian kualitatif dengan studi pustaka sebagai proses pencarian datanya. Studi pustaka yang dimaksud adalah dengan mengamati website ANRI. Analisa dilakukan dengan menjawab pertanyaan-pertanyaan yang ada dalam metode Ten C's. Hasil analisa selanjutnya disajikan dalam bentuk paragraf deskriptif. Model paragraf yang digunakan adalah paragraf deduktif dimana setiap paragraf diawali dengan suatu pernyataan utama dan diikuti dengan beberapa pernyataan pendukung.

\section{Pembahasan}

Dalam pembahasan ini, untuk memudahkan pembaca, maka hasil penelitian disajikan melalui pengelompokan berdasarkan indikator yang ada sebagai berikut.

\section{Content}

Pada dasarnya website ANRI digunakan untuk menampilkan seluruh informasi mengenai ANRI. Namun, usaha tersebut justru berimbas pada ketidak fokusan isi dari website yang ditampilkan. Hal ini terlihat dengan adanya berbagai menu dan konten yang saling tumpang tindih.

Salah satu kelemahan dari website ini adalah banyaknya jenis informasi pada halaman pertama. Penampilan informasi di halaman pertama menjadi suatu hal yang penting dalam rangka memberikan kesan pertama yang menarik bagi pengunjung. Namun, jika keberagaman jenis informasi yang disajikan terlalu banyak, hal tersebut justru menyebabkan pengunjung merasa kesulitan untuk mengidentifikasi informasi yang ditampilkan.

Masing-masing informasi yang dicantumkan dapat diidentifikasi dari judul tulisan. Hanya saja, tidak semua informasi tersebut disertai dengan nama-nama penulis. Hal ini menyebabkan pengunjung menjadi kesulitan untuk mengutip informasi yang ada dikarenakan tidak adanya kejelasan siapa penulis artikel tersebut.

Konten yang ditampilkan adalah konten yang berisi informasi mengenai kearsipan. Konten tersebut juga mengalami pembaharuan secara kontinyu. Hal ini dapat dilihat dari tanggal informasi terbaru yang ditampilkan yaitu pada tanggal 01 Juli 2011.

\section{Credibility}

Pada dasarnya informasi mengenai pengelola dapat diidentifikasi oleh pengunjung. Hal ini dapat dilihat dari adanya informasi alamat, nomor telpon, fax, dan email dari pengelola. Namun, letak informasi 
yang berada di bagian bawah menyebabkan pengunjung sedikit kesulitan untuk menemukannya. Pengunjung baru dapat menemukan informasi tersebut setelah melakukan scroll down. Selain itu, seperti disebutkan di atas, banyaknya informasi yang ditampilkan menyebabkan pengunjung harus jeli untuk mendapatkan informasi mengenai pengelola website.

Konten yang ditampilkan dapat trejaga kredibilitasnya. Meskipun beberapa artikel tidak disertai dengan nama penulisnya, namun dengan membawa nama lembaga ANRI, maka pengelola website cukup berhati-hati dalam menampilkan artikel. Hal ini dapat dilihat dari kaedah penulisan yang digunakan. Artikel yang dimuat telah menggunakan kaedah penulisan yang baku. Selain itu, kredibilitas tersebut dapat dilihat dengan kesesuaian ekstensi website, yaitu '.go.id' yang mencerminkan bahwa website tersebut merupakan website pemerintahan.

\section{Critical Thinking}

Dilihat dari tampilan yang ada, website tersebut dibangun oleh orang yang telah berpengalaman di bidangnya. Meskipun pada dasarnya terdapat beberapa kelemahan di dalamnya, namun jika dilihat lebih lanjut akan terlihat bahwa tujuan dari pengelola website ini adalah untuk menampilkan informasi sebanyak-banyaknya.

Beberapa dokumen arsip yang dapat diunduh oleh para pengunjung telah dilengkapi dengan pembuat, penerbit, serta edisi. Dikarenakan website ini merupakan website lembaga kearsipan negara, maka beberapa dokumen yang dapat diunduh merupakan dokumen yang ditulis dan diterbitkan oleh lembaga negara. Sehingga edisi yang dimaksud adalah edisi dalam hal nomor dan tahun arsip.

Mengenai kriteria yang dapat digunakan dalam evaluasi website ini, menurut penulis, berbagai kriteria dapat diterapkan. Hal-hal seperti kompatibilitas, viibilitas, kemudahan akses, dan lain lain dapat dijadikan sebagai kriteria-kriteria evaluasi website ANRI.

\section{Copyright}

Untuk dokumen yang bisa diunduh, terutama arsip peraturan perundang-undangan disertai dengan pernyataan hak cipta. Pernyataan tersebut terdapat pada bagian bawah masing-masing halaman. Namun, untuk dokumen lain seperti laporan dan artikel tidak disertai dengan pernyataan hak cipta. Hal ini menyebabkan sulitnya proses pertanggungjawaban. Meskipun demikian, dokumen laporan dan artikel tersebut dilengkapi dengan nama penulisnya sehingga, menurut hemat penulis, nama penulisnyalah yang memegang hak cipta artikel tersebut.

Berbeda dengan dokumen yang bisa diunduh, informasi yang ditampilkan pada halaman website tidak disertai dengan pernyataan hak cipta serta kepengarangan. Hal ini tentu saja membuat pengunjung mempertanyakaan pertanggungjawaban informasi yang dimuat. Oleh karena itu, sebaiknya dalam informasi yang ditampilkan, minimal disertai dengan nama penulis. 


\section{Citation}

Isi website merupakan informasi yangn dihasilkan oleh kegiatan internal lembaga kearsipan ANRI. Sehingga informasi yang ditampilkan bukanlah kutipan dari media lain. Namun, dikarenakan beberapa artikel tidak disertai dengan daftar kutipan, maka dasar hukum dari tulisan yang dimuat dipertanyakan. Meskipun di dalam artikel disebutkan pernyataan mengenai peraturan-peraturan yang digunakan, namun jika tidak disertai dengan daftar peraturan yang dikutip maka landasan hukum pengutipan tersebut masih tetap dipertanyakan.

\section{Continuity}

Dilihat dari update informasi yang yang ada, maka kontinuitas website ini tergolong cukup baik. Informasi-informasi terbaru mengenai kearsipan selalu diperbaharui. Dalam hal perubahan nama domain, website ANRI belum pernah melakukan perubahan nama domain sehingga informasi yang ada tetap mudah didapatkan.

Beberapa dokumen yang dapat diunduh oleh pengunjung merupakan pembaharuan dari dokumen pada edisi sebelumnya. Salah satunya adalah mengenai peraturan-peraturan seperti peraturan mengenai jadwal retensi arsip yang terbit pada tahun 2000. Pada tahun berikutnya, tahun 2003, muncul Kepka Nomor 01.A Tahun 2003 Tentang Jadwal Retensi Arsip Keuangan. Peraturan tersebut merupakan bagian dari penjelasan dari peraturan retensi arsip yang telah dikeluarkan pada tahun 2000. Hal ini mendapatkan perhatian dari ANRI dengan menerbitkan peraturan terbaru mengenai retensi arsip tersebut di atas.

\section{Censorship}

Website ini dilengkapi dengan kolom kritik dan saran yang berfungsi sebagai interaksi antara pengunjung dengan pengelola website. Setiap pengunjung dapat memberikan kritik dan sarannya sesuai dengan kolom yang disediakan dan disertai dengan nama dan alamat email yang bersangkutan. Namun, berdasarkan pengalaman penulis, kritik dan saran tersebut tidak mendapatkan respon yang baik dari pengelola. Ketika penulis mengirimkan pertanyaan melalui kolom kritik dan saran, pengelola tidak mengirimkan respon sebagai jawaban dari pertanyaan yang diajukan. Hal ini menyebabkan fungsi dari kolom kritik dan saran tersebut kurang maksimal.

Keyword pencarian untuk website ini dapat dilakukan secara sembarang. Kata kunci seperti arsip, kearsipan, dan lembaga arsip dapat digunakan sebagai kata kunci pencarian untuk menemkan website menggunakan mesin pencari. Terkait dengan masalah visi dan misi, website ini dilengkapi dengan visi dan misi kelembagaan yang jelas, sehingga pembatasan informasi yang ditampilkan juga didasarkan ada visi dan misi tersebut. Sedangkan mengenai privasi, setiap pengunjung akan terjaga privasinya.

\section{Connectivity}


Dikarenakan banyaknya informasi pada halaman pertama, disertai dengan adanya diorama yang ditampilkan menyebabkan website ini memiliki konektivitas yang kurang. Pada jam-jam tertentu, seperti siang hari, website ini akan semakin sulit untuk diakses. Namun, setiap pengunjung dapat melakukan akses dengan berbagai model koneksi, seperti melalui jaringan kabel, nirkabel, dan hp. Khusus akses dengan hp, maka konektivitas website akan semakin lambat dikarenakan bannyaknya konten yang ditampilkan.

Untuk mendapatkan hasil yang terbaik, maka pengunjung disarankan untuk menggunakan web browser yang disertai dengan grafik dan animasi. Software utama yang dibutuhkan adalah aplikasi flash player. Hal ini juga yang menyebabkan konektivitas akses menjadi menurun.

\section{Compatibility}

Website dapat disimpan dalam media penyimpanan lain. Namun, proses penyimpanan menjadi lambat, lagi-lagi dikarenakan banyaknya conten yang disertakan. Disamping itu, penyimpanan pada media lain akan merubah tampilan website yang disimpan. Hal ini wajar dikarenakan ketika suatu website dipindah ke media lain maka pada dasarnya ada beberapa konten yang tidak ikut tersimpan. Kondisi seperti inilah yang menyebabkan tampilan website menjadi tidak sempurna.

Informasi yang ditampilkan cukup lengkap. Informasi yang ada mencakup peraturan, artikel, laporan, informasi kegiatan, dan informasi lain terkait dengan kearsipan. Website ini juga dilengkapi dengan informasi statistik pengunjung. Dengan demikian, pengunjung dapat melihat berapa banyak website ini pernah dikunjungi.

Keberadaan informasi tanggal pemuatan menjadikan pengunjung mudah membedakan informasi lama dan informasi terbaru. Masing-masing informasi yang ditampilkan disertai dengan tanggal pemuatan. Hal ini merupakan nilai tambah tersendiri bagi website ANRI.

\section{Context}

Website ANRI bukanlah website ilmiah. Namun, website ini dilengkapi dengan artikel dan dokumen-dokumen yang dapat digunakan dalam mendukung penelitian. Pengunjung dapat menemukan dokumen-dokumen tersebut dengan menuju link yang telah disediakan.

\section{Kesimpulan}

Dari hasil pemaparan di atas, selain berbagai kelebihan seperti kelengkapan informasi, kejelasan visi dan misi, dan kebaruan informasi, website ANRI juga memiliki beberapa kelemahan. Kelemahan yang ada terkait dengan terlalu banyaknya konten yang ditampilkan, beberapa artikel tidak dilengkapi dengan penulis, dan konektivitas yang lambat pada jam-jam tertentu. Oleh karena itu, dalam rangka 
perbaikan, penulis menyarankan agar pengelola website ANRI untuk lebih memperhatikan hal-hal tersebut di atas.

\section{Daftar Pustaka}

Feather, John dan Paul Sturges. 2003. International Encyclopedia of Information and Library Science. Second edition. London: Routledge.

Mortimer, Mary. 2007. Library Speak: A glossary of term in librarianship and information management. Texas: Total Recall Publication.

Prytherch, Ray. 2005. Harrod's Librarians' Glossary and Reference Book: A directory of over 10,200 terms, organizations, projects and acronyms in the areas of information management, library science, publishing and archive management. England: Ashgate.

Stevenson, Janet dan P. H. Collin. 2006. Dictionary of Information and Library Management. Second edition. London: A \& C Black.

Artana, Ketut Buda dan Suhartono. 2009. "Evaluasi Web Personal Dosen Its Bulan April dan Agustus 2009 Berkaitan Dengan Peringkat ITS Pada Webometrics" dalam http://www.its.ac.id/personal/files/material/1363-suhartono-statistics-

Webometrics_Report_Juli_2009.pdf/diakses pada 03 Juli 2011 pukul 07:18 WIB.

Rusidi, Lin Yan Syah dan Muhamad Akbar. 2011. "Evaluasi Website E-Government Instansi Pemerintah Daerah Kabupaten Ogan Komering Ulu dan Ogan Komering Ulu Timur" dalam http://blog.binadarma.ac.id/akbar/?p=225/ diakses pada 03 Juli 2011 pukul 07:28 WIB.

Hendrayudi, Lin Yan Syah dan Muhamad Akbar. 2011. "Evaluasi Website Pemerintah Daerah Berdasar Layanan Antar Lembaga Pemerintah, Pemerintah Kepada Dunia Usaha dan Pemerintah Kepada Warga Negara" dalam http://blog.binadarma.ac.id/akbar/?p=230/ diakses pada 03 Juli 2011 pukul 07:32 WIB.

Richmond, Betsy. 2011. "Ten C's For Evaluating Internet Sources" dalam http://www.montgomerycollege.edu/Departments/writegt/htmlhandouts/Ten_C_internet_sources. htm/ diakses pada 03 Juli 2011 pukul 08:06 WIB. 